\title{
GENETIC EVALUATION OF SEEDLING HEAT TOLERANCE IN SORGHUM
}

\author{
P.S. SETIMELA, D.J. ANDREWS ${ }^{1}$, K.M. ESKRIDGE ${ }^{1}$ and J. PARTRIDGE ${ }^{1}$ \\ CIMMYT- Zimbabwe, P.O. Box MP 163, Harare, Zimbabwe \\ ${ }^{1}$ Department of Agronomy, University of Nebraska, Lincoln, NE, 68583, USA
}

(Received 9 December, 2006; accepted 1 March, 2007)

\begin{abstract}
Surface temperatures of tropical soils at planting time, where sorghum (Sorghum bicolor) is a traditional crop, can exceed $50{ }^{\circ} \mathrm{C}$ for hours. Seedling heat tolerance is critical for adequate crop establishment in the semi-arid tropics. Improvement of seedlings heat tolerant genotypes would reduce crop losses due to sufficient plant populations. The objectives of this study were to estimate seedling tolerance to heat, determine individual parental contribution and estimate additive, dominance and epistatic effects for seedling tolerance. In our experiments, seedling heat tolerance termed heat tolerance index (HTI) was defined as a ratio of resumed coleoptile growth after a controlled heat shock, compared to normal growth. Genetic parameters of HTI were determined by crossing four lines with varying HTI, with three tester lines, and deriving $F_{1}, F_{2}, F_{3} B_{1}$ and $B_{11}$ families for generation means analysis. Line IS20969 from Egypt showed the highest HTI of 0.71, while 290R, an experimental line from the University of Nebraska was the lowest at 0.51 . Additive and dominance effects contributed to coleoptile elongation under normal conditions, but only additive effects were significant in recovery growth. Epistatic effects were present in both conditions. General combining ability (GCA) effects for HTI were highly significant in both conditions, but specific combining ability effects were negligible. These results indicate that it is possible to improve seedling heat tolerance and, thus, improve sorghum variety and hybrid plant populations in tropical areas where hot soil temperatures occur.
\end{abstract}

Key Words: Combining ability, genetic effects, heat tolerance index, sorghum bicolor

\section{RÉSUMÉ}

Les températures en surface des sols tropicaux au moment des semis, où le sorgho est une récolte traditionnelle, peuvent excéder $50^{\circ} \mathrm{C}$ pendant des heures. La tolérance de la chaleur des plantes est critique pour l'établissement adéquat de la culture dans les tropiques semi-arides. L'amélioration des génotypes résistants à la chaleur de plantes réduirait des pertes de récolte dues aux populations de plantes suffisantes. L'objectif de cette étude était d'estimer la tolérance des plantes a la chaleur, déterminer l'additif parental individuel de contribution et d'évaluation, la dominance et les effets épistatiques pour la tolérance des plantes en utilisant des analyses de moyens de génération des populations développées à partir de l'ensemble de détail de parents. Dans nos expériences, la tolérance de la chaleur des plantes l'index nommé de tolérance de la chaleur (HTI) a été définie comme rapport de croissance reprise de coléoptile après un choc commandé de la chaleur, comparé à la croissance normale. Des paramètres génétiques de HTI ont été déterminés en croisant quatre lignes de différents HTI avec trois lignes d'appareil de contrôle, et dérivant les familles $\mathrm{F}_{1}, \mathrm{~F}_{2}, \mathrm{~F}_{3}, \mathrm{BC}_{1}$ et $\mathrm{BC}_{11}$ pour la génération veut dire l'analyse. La ligne IS20969 d'Egypte a montré le plus haut HTI de 0.71 tandis que 290R, une ligne expérimentale de l'université du Nébraska, était la plus basse à 0.51. L'additif et les effets de dominance ont contribué à l'élongation de coléoptile dans des conditions normales, mais uniquement les effets additifs étaient significatifs dans la croissance de rétablissement. Les effets épistatiques étaient présents dans les deux conditions. Les effets de combinaison généraux de la capacité (GCA) pour HTI étaient fortement significatifs dans les deux conditions mais les effets de combinaison spécifiques de capacité étaient négligeables. Ces résultats indiquent qu’il est possible d’améliorer la 
tolérance de la chaleur pour des plantes améliores et d'améliorer ainsi la variété de sorgho et les populations de plantes hybrides dans des secteurs tropicaux avec de fortes températures de sol.

Mots Clés: Combining ability, genetic effects, heat tolerance index, sorghum bicolor

\section{INTRODUCTION}

Sorghum (Sorghum bicolor L. Moench) evolved in the semi-arid tropics, which are characterised by low rainfall, low soil fertility and high temperatures. Despite the level of its adaptation to the semi-arid tropics, seedling establishment is still a major problem. Failure of seedling establishment due to heat stress is one of the key factors that limit yields and affect stability of production in the semi-arid tropics (Peacock, 1982). According to Radford et al. (1989), only $55 \%$ of sorghum seed planted in the field in Australia resulted in successful plants. They also estimated that in Australia, sorghum growers lose $30 \%$ of the potential yields due to inadequate plant populations. Uniformity in the establishment of crop stands is one of the essential factors to obtaining a full yield under any production system.

A wide range of genetic attributes for thermal tolerance has been reported in many crop species (Levitt,1980). Thomas and Miller (1979) reported that sorghum seedlings respond differently when exposed to varying temperatures, and genetic variation for thermal tolerance in sorghum has been shown to exist in certain lines that are cable of emerging at soil temperature of about $55{ }^{\circ} \mathrm{C}$ (Wilson et al., 1982) Beside sorghum, Allan et al. (1962) observed varietal differences in wheat with one variety emerging more evenly in some fields than other varieties under high temperatures conditions. Peacock et al. (1993) and Howarth (1989) have discussed the need for greater diversity in sorghum seedling tolerance to heat in superior genotypes, as this will improve crop establishment in the semi-arid tropics. Genotypes with heat tolerance can be developed as it has been done for other traits such as diseases and insect resistance (Miller, 1982).

The objectives of the study reported herein were to gather information on the expression of heterosis of seedling heat stress, understand the contribution of individual parental lines and to estimate additive, dominance and epistatic effects for seedling heat tolerance by utilising generation means analyses using populations developed from a specific set of parents.

\section{MATERIALSAND METHODS}

Experimental materials. This study was based on four genetically diverse sorghum lines and 3 testers (inbred lines used to test the value of genotypes based on performance of their offspring). The genotypes were chosen on the basis of their variable response to heat stress. Three of the parental lines, are known sources of, heat tolerance; IS20969 a late maturing resistant line from Kenya; Segaolane of intermediate maturity from Botswana; IS1347 an early Egyptian maturing line; 290R was obtained from the University of Nebraska (UNL) experimental line susceptible to heat stress. Three testers were used, namely, CK60A \& B a previously widely used Texas seed parent with moderate heat tolerance, N250A\&B and N252A\&B, two genetically different recent seed parent releases from UNL breeding programme of unknown heat tolerance.

Each parent line was crossed to each tester, producing $12 \mathrm{~F}_{1}$ hybrids; from each $\mathrm{F}_{1}$ the following generations were developed: $\mathrm{BC}_{1}$ (backcross to parent line only), $\mathrm{BC}_{11}\left(2^{\text {nd }}\right.$ backcross to parent line), $\mathrm{F}_{2}$ and $\mathrm{F}_{3}$. The $12 \mathrm{~F}_{1}$ hybrids were produced using tester cytoplasmic male sterility A-lines but $\mathrm{F}_{1} \mathrm{~s}$ for deriving progeny were made by plastic bag emasculation on the male fertile line, as were the $\mathrm{BC}_{1}$ and $\mathrm{BC}_{11} \mathrm{x} \mathrm{F}_{1} \mathrm{~s}$. Because this method does not ensure complete crossing, hybrid plants were identified in each $\mathrm{F}_{1}$ row.

Laboratory techniques. Seeds were first cleaned and a uniform median seed size of each genotype was obtained by sieving, which reduced variation within genotypes for seed size. Seeds were surface sterilised by immersion in a hypochlorite 
solution (1\% available chlorine) for 5 minutes and then rinsed thoroughly with distilled water. Fifty seeds from each genotype were placed on a germination paper, moistened with distilled water, and germinated in an incubator for $40 \mathrm{~h}$ at $30^{\circ} \mathrm{C}$. Germinated seeds (defined to have occurred after $1 \mathrm{~mm}$ protrusion of the radicle) were exposed to heat shock using standard procedures and methods described by Setimela et al. (2004).

One set from a replication of a generation block was subjected to a direct heat shock by placing the seedlings in a controlled temperature water bath at $50{ }^{\circ} \mathrm{C}$ for 10 minutes. The other set of seedlings of the same genotypes were treated similarly but without any heat shock. Prior to treatment, photocopies were taken of all plates to record coleoptile length to derive plot means. Following the treatments the seedlings were returned to the $30^{\circ} \mathrm{C}$ growth chamber. After $36 \mathrm{~h}$, the length was measured, by photocopying the numbered plates and obtaining the lengths of 10 randomly selected coleoptiles.

Statistical design and analysis. The experiment was performed as replication-within block design due to larger number of entries following a procedure outlined by Comstock and Robinson (1948) and Ross and Gardner (1983). The procedure takes each generation as a block. Each block had 5 replications and the same set of generation. This design allowed the comparison of genotypes within the same generation. The entries per set and the sets per generation remained together in the second replication but were again randomised. Each generation experiment can be treated as a small randomised complete block design, involving a set of generations. The parents were included in each generation experiment and the overall mean of the parents in a replication was subtracted from all the entries in that replication were used to remove the variation among generations so that entries are not confounded within blocks. Based on the adjusted values the experiment was reanalysed as a randomised complete block design.

Data were subjected to analysis of variance to account for differences among generations. General and specific combining abilities were estimated and tested based on adjusted means. Estimates of genetic effects for each cross were determined by subjecting all populations to generation means analysed by procedure out lined by Hallauer and Miranda (1988). Least squares regression techniques were used on adjusted mean to obtain estimates of parameters: $\mathrm{m}$, a, d, aa, ad and dd which, respectively, represent means based on the $\mathrm{F}_{2}$ additive effects, dominance effects, additive $\mathrm{x}$ additive effects, additive $\mathrm{x}$ dominance effects, and dominance $\mathrm{x}$ dominance effects.

Heat tolerance per se was expressed by heat tolerance index (HTI) defined as a ratio of resumed coleoptile growth after the controlled heat shock (exposure time $10 \mathrm{~min}$ at $50^{\circ} \mathrm{C}$ ) compared to normal growth.

\section{RESULTSAND DISCUSSION}

Significant differences were detected among generations in the analysis of variance for coleoptile elongation under normal growth (UNG), after heat exposure (EXP) and for the derived heat tolerance index (HTI) (Table 1). The HTI values of lines, $\mathrm{F}_{1}$ and derived generations are listed in Table 2. There were highly significant $(\mathrm{P}<0.05)$ differences among genotypes under UNG, EXP and for HTI. There were significant differences between lines and testers in crosses under normal growth and controlled heat shock, but lines vs. testers were only significant for HTI. Similarly, there was remarkable difference between testcrosses and parental lines under heat shock and normal growth. However, testers did not contribute significantly $(\mathrm{P}>0.05)$ to differences in heat recovery indices, only CK60A contributed significantly to increased coleoptile growth under normal conditions and under controlled heat shock in its hybrids. Hybrids in general, had higher UNG and EXP values than testers or parental lines, which is an expression of heterosis (Tables 2 and 3).

The average UNG of IS20969 test crosses was significantly $(\mathrm{P}<0.05)$ better than IS20969, which had the best coleoptile elongation under UNG, EXP and HTI values of any parent (Tables 2, 3 and 4). However, because the EXP of IS20969 test crosses was not better than the parent per se, their HTI were in fact significantly worse than of the higher parent. Segaolane testcrosses though had average EXP and HTI, and were 
TABLE 1. Analysis of variance showing $F$ tests of seedling elongation ( $\mathrm{mm}$ ) with exposed EXP) and without (UNG) heat stress at 50 degree Celsius for 10 minutes and derived recovery heat index ( $\mathrm{HTI}$ ) for sorghum lines, testers and test crosses

\begin{tabular}{|c|c|c|c|c|}
\hline \multirow[b]{2}{*}{ Sources of variation } & \multicolumn{4}{|c|}{ F-values } \\
\hline & d.f. & UNG & EXP & $\mathrm{HTI}$ \\
\hline Blocks & 3 & $22.05^{\star \star}$ & $6.97^{\star \star}$ & 2.17 N.S \\
\hline Replications (Blocks) & 20 & & & \\
\hline Genotypes (Blcoks) & 76 & $8.85^{\star \star}$ & $13.54^{\star *}$ & $2.42^{\star \star}$ \\
\hline Hybrids & 11 & $7.41^{\star \star}$ & $7.63^{\star \star}$ & 1.44 N.S \\
\hline Lines & 3 & $24.18^{\star \star}$ & $18.84^{\star \star}$ & $7.10^{\star *}$ \\
\hline Testers & 2 & 1.47 N.S & $2.30^{*}$ & .32 N.S \\
\hline Lines and Testers & 6 & $12.65^{\star \star}$ & $10.47^{\star *}$ & $4.01^{\star \star}$ \\
\hline Parents per se & 6 & $12.65^{\star \star}$ & $10.47^{\star \star}$ & $4.01^{\star \star}$ \\
\hline Testers per se & 2 & 1.47 N.S & $2.30^{*}$ & $.32 \mathrm{~N} . \mathrm{S}$ \\
\hline Lines per se & 3 & $24.18^{\star \star}$ & $18.84^{\star \star}$ & $7.10^{\star *}$ \\
\hline Tester vs Lines & 1 & .39 N.S & 1.71 & $2.15^{\star}$ \\
\hline Test crosses vs Parents & 1 & $13.09 * \star$ & $27.37^{\star \star}$ & 0.07 N.S \\
\hline Generations (Blocks) & 18 & $4.82^{\star \star}$ & $3.63^{\star \star}$ & $1.32^{*}$ \\
\hline F2 & 11 & $3.55^{\star}$ & $5.83^{\star \star}$ & $3.01^{\star \star}$ \\
\hline F3 & 11 & $5.68^{\star \star}$ & $22.44^{\star \star}$ & $4.67^{\star \star}$ \\
\hline Backcrosses & 19 & $13.86^{\star \star}$ & $20.55^{\star \star}$ & $1.67^{\star}$ \\
\hline
\end{tabular}

d. $f=$ degrees of freedom; ${ }^{*}$, ${ }^{*}=$ Significant at the 0.05 and 0.01 probability levels, respectively; and \# for F1 generation see hybrids

significantly better in these parameters than line itself because Segaolane had below average EXP and HTI values. Though IS1347 did not produce any significant differences, it numerically gave the best HTI with CK60A and N250A and was average with N252A. The experimental line (290R) had low UNG and EXP values; though the UNG and EXP of all 290R testcrosses were the lowest, they were significantly better than 290R per se their HTI showed no change.

There were highly significant GCA effects for specific lines with and without heat stress. The GCA effects were consistent among lines with and without heat stress (Table 5). Lines IS20969 and 290R combined well with testers for UNG by highly significant GCA toward the hybrids. The HTI was significant for 290R, but not significant for all other lines. In terms of GCA, IS20969 and
290R were the only parents, which had highly significant estimate $(\mathrm{P}=0.001)$ for $\mathrm{GCA}$ for coleoptile elongation for UNG and EXP(Table 5). The estimate for GCA for IS20969 was negative, while that of 290R was positive. The signs are expected between the two parents since they have varying degree of tolerance to heat stress. Heterotic effects, however, were in both positive and negative directions with respect to high and low parents. The SCA estimates are ultimately important to test the performance of parents in hybrid combinations. The best parents could be used to produce hybrids. In the present study none of the crosses had significant SCA effects for coleoptile elongation for UNG and EXP. Heterosis in the $F_{1}$ generation was mostly due to GCA. 
TABLE 2. Means for coleoptile elongation (mm) of sorghum parental, F1, F2,F3, and backcross generations without (UNG) heat stress crosses

\begin{tabular}{|c|c|c|c|c|c|c|c|}
\hline \multirow[b]{2}{*}{ Cross } & \multicolumn{7}{|c|}{ Generation } \\
\hline & Lines & Testers & $\mathrm{F} 1$ & $\mathrm{~F} 2$ & F3 & $\mathrm{BC} 1$ & BC11 \\
\hline IS20969 & 80 & & & & & & \\
\hline Ck60A x IS20969 & & 69 & 103 & 71 & & 64 & 68 \\
\hline N250A x IS20969 & & 76 & 96 & 77 & 77 & 69 & 80 \\
\hline N252A x IS20969 & & 69 & 85 & 79 & 60 & & 72 \\
\hline Segaolane & 74 & & & & & & \\
\hline CK60A x Segaolane & & 69 & 84 & 74 & 52 & 74 & 41 \\
\hline N250A x Segaolane & & 76 & 92 & 78 & 60 & 53 & \\
\hline N252A x Segaolane & & 69 & 76 & 80 & 60 & 71 & 51 \\
\hline IS1347 & 73 & & & & & & \\
\hline CK60A X IS1347 & & 69 & 81 & 61 & 61 & 38 & 75 \\
\hline N250A x IS1347 & & 76 & 80 & 73 & 64 & 66 & \\
\hline IS1347 x N252A & & 69 & 67 & 70 & 67 & 63 & \\
\hline $290 R$ & 44 & & & & & & \\
\hline CK60A $\times 290 R$ & & 69 & 72 & 57 & 54 & 53 & 40 \\
\hline $\mathrm{N} 250 \mathrm{~A} \times 290 \mathrm{R}$ & & 76 & 67 & 57 & 63 & 49 & 47 \\
\hline $\mathrm{N} 252 \mathrm{~A} \times 290 \mathrm{R}$ & & 69 & 64 & 69 & 48 & 47 & 46 \\
\hline Mean & 68 & 71 & 81 & 71 & 61 & 58 & 59 \\
\hline SE & 2.07 & 3.99 & 3.99 & 3.99 & 3.99 & 3.99 & 3.99 \\
\hline
\end{tabular}

An additive-dominance model fits the data in most of the crosses. The data fitted a more complex model (epistasis) in two crosses involving N250A x IS20969 for UNG and N250A x Segaolane for EXP conditions (Tables 6 and 7). Five of the crosses, had significantly negative additive effects except for a cross involving CK60A x Segaolane under normal conditions. Six of the crosses had a positive significant dominance effect (Table 6). The magnitude of dominance was higher than the additive effects in most of the crosses. Additive $\mathrm{x}$ additive epitasis gene effects were significant only in two crosses. Most of the crosses involving the parental line IS20969 had positive significant additive effects and crosses involving 290R had negative significant additive gene effects. The above results indicate that under normal growth both dominant and additive gene effects play a major role for coleoptile elongation.
Contrary to normal growth under controlled shock, 10 of the 12 crosses had a significant additive gene effect and only 4 of the crosses had a significant dominance gene effect (Table 7). Two of the crosses involving IS20969 contributed positively to coleoptile elongation under controlled heat shock and all the crosses involving 290R have significantly negative additive effects. The contribution between the 2 parental lines is expected due to their different levels of heat tolerance. The contribution of epistasis to coleoptile length under heat stress was significant only in 1 cross (N250A x Segaolane) indicating that for this particular cross, inheritance of heat tolerance is complex. The additive $\mathrm{x}$ additive gene interaction was positive while additive $\mathrm{x}$ dominance gene interaction was negative. The epistasis gene with positive and negative effects may have a negative impact on coleoptile elongation as the effects cancel each 
TABLE 3. Means for Coleoptile elongation (mm) of sorghum parental, F1,F2,F3 and backcross generations when exposed (EXP) to heat stredss at $50^{\circ} \mathrm{C}$ for 10 minutes

\begin{tabular}{|c|c|c|c|c|c|c|c|}
\hline \multirow[b]{2}{*}{ Cross } & \multicolumn{7}{|c|}{ Generations } \\
\hline & Lines & Testers & $F_{1}$ & $\mathrm{~F}_{2}$ & $\mathrm{~F}_{3}$ & $\mathrm{BC} 1$ & BC11 \\
\hline IS20969 & 57 & & & & & & \\
\hline Ck60A x IS20969 & & 46 & 61 & 38 & & 36 & 43 \\
\hline N250A x IS20969 & & 44 & 61 & 50 & 51 & 47 & 48 \\
\hline N252A x IS20969 & & 41 & 53 & 51 & 33 & & 48 \\
\hline Segaolane & 40 & & & & & & \\
\hline CK60A $\times$ Segaolane & & 46 & 52 & 44 & 26 & 40 & 25 \\
\hline N250A x Segaolane & & 44 & 54 & 31 & & 30 & \\
\hline N252A x Segaolane & & 41 & 42 & 38 & 34 & 45 & 31 \\
\hline IS1347 & 52 & & & & & & \\
\hline CK60A X IS1347 & & 46 & 52 & 39 & 46 & 28 & 46 \\
\hline N250A x IS1347 & & 44 & 55 & 45 & 47 & 47 & \\
\hline IS1347 x N252A & & 41 & 39 & 49 & 41 & 45 & \\
\hline $290 \mathrm{R}$ & 22 & & & & & & \\
\hline CK60A x 290R & & 46 & 43 & 31 & 28 & 30 & 20 \\
\hline $\mathrm{N} 250 \mathrm{~A} \times 290 \mathrm{R}$ & & 44 & 40 & 32 & 28 & 26 & 28 \\
\hline $\mathrm{N} 252 \mathrm{~A} \times 290 \mathrm{R}$ & & 41 & 35 & 42 & 27 & 30 & 25 \\
\hline Mean & 43 & 44 & 50 & 42 & 37 & 35 & 36 \\
\hline SE & & 1.58 & 1.58 & 2.99 & 2.99 & 2.99 & 2.99 \\
\hline
\end{tabular}

_- Missing data

other (Mather and Jinks, 1982). The performance may depend on the magnitude of the epistasis of the cross involved.

With reference to derived HTI, eight crosses had significant additive gene effects and only 1 cross had significantly negative dominant effects (Table 8). The crosses involving IS20969 had significantly positive additive effects and crosses involving 290R had a significantly negative additive gene effect. The predominance of additive gene action for coleoptile elongation under controlled heat shock suggests that improvement can be achieved by selecting in the early generations. The lack of significant SCA for coleoptile elongation indicates that under heat stress; additive gene effects mostly influence elongation. Analysis of variance of the crosses among lines indicated that most of the variation within each set of crosses was attributable to GCA of the lines included in the crosses. These results indicate that when parents have poor coleoptile elongation, significant heterosis manifests, and when coleoptile elongation is intermediate, negative heterosis is observed. Crosses that have lower decline in heterosis across generations indicate less inbreeding depression.

\section{CONCLUSION}

In this study the focus was on seedling tolerance or sensitivity to heat and does not imply resistance or sensitivity to any other stage, although the genotypes were selected based on the level of tolerance or sensitivity on mature plants in the field. Heat tolerant lines did not contribute significantly to hybrids with heat tolerant testers but heat tolerant lines contributed positively to hybrid performance when poor testers were used as pollinators. Dominance 
TABLE 4. Means fopr derived heat recovery index based on resumed coleoptile elongation after controlled heat shock $50^{\circ} \mathrm{C}$ for 10 min in sorghum parental line F1, F2, F3 and backcross generation

\begin{tabular}{|c|c|c|c|c|c|c|c|}
\hline \multirow[b]{2}{*}{ Cross } & \multicolumn{6}{|c|}{ Generations } & \multirow[b]{2}{*}{ BC11 } \\
\hline & Lines & Testers & $\mathrm{F}_{1}$ & $\mathrm{~F}_{2}$ & $\mathrm{~F}_{3}$ & $\mathrm{BC} 1$ & \\
\hline IS20969 & 0.71 & & & & & & \\
\hline Ck60A x IS20969 & & 0.66 & 0.59 & 0.54 & 0.56 & 0.63 & \\
\hline N250A x IS20969 & & 0.6 & 0.64 & 0.64 & 0.67 & 0.71 & 0.7 \\
\hline N252A x IS20969 & & 0.6 & 0.62 & 0.65 & 0.54 & 0.73 & \\
\hline Segaolane & 0.55 & & & & & & \\
\hline CK60A x Segaolane & & 0.66 & 0.61 & 0.59 & 0.48 & 0.53 & 0.64 \\
\hline N250A x Segaolane & & 0.6 & 0.59 & 0.62 & 0.5 & & 0.57 \\
\hline N252A x Segaolane & & 0.6 & 0.56 & 0.61 & 0.55 & 0.63 & 0.63 \\
\hline IS1347 & 0.71 & & & & & & \\
\hline CK60A X IS1347 & & 0.66 & 0.66 & 0.64 & 0.74 & 0.73 & 0.63 \\
\hline N250A x IS1347 & & 0.6 & 0.71 & 0.62 & 0.73 & 0.7 & \\
\hline IS1347 x N252A & & 0.6 & 0.58 & 0.69 & 0.54 & 0.73 & \\
\hline $290 \mathrm{R}$ & 0.51 & & & & & & \\
\hline CK60A $\times 290 R$ & & 0.66 & 0.6 & 0.54 & 0.52 & 0.59 & 0.53 \\
\hline $\mathrm{N} 250 \mathrm{~A} \times 290 \mathrm{R}$ & & 0.6 & 0.59 & 0.57 & 0.46 & 0.53 & 0.6 \\
\hline $\mathrm{N} 252 \mathrm{~A} \times 290 \mathrm{R}$ & & 0.6 & 0.55 & 0.6 & 0.55 & 0.64 & 0.54 \\
\hline Mean & 0.62 & 0.62 & 0.61 & 0.61 & 0.57 & 0.62 & 0.63 \\
\hline SE & 0.02 & 0.02 & 0.04 & 0.04 & 0.04 & 0.04 & 0.04 \\
\hline
\end{tabular}

TABLE 5. General combining abilities of lines (GCAL) for coleoptile elongation for without (UNG) and with (EXP) to heat stress at $50^{\circ} \mathrm{C}$ for 10 minutes and derived recovery growth index $(\mathrm{HTI})$

\begin{tabular}{|c|c|c|c|c|c|c|}
\hline \multirow[b]{2}{*}{ Lines } & \multicolumn{2}{|c|}{ UNG } & \multicolumn{2}{|c|}{ EXP } & \multicolumn{2}{|c|}{$\mathrm{HTI}$} \\
\hline & GCAL & $S E$ & GCAL & SE & GCAL & SE \\
\hline IS20969 & $13.85^{\star \star}$ & 2.17 & -9.37 & 1.64 & 0.016 & 0.019 \\
\hline Segaolane & -3.45 & 2.17 & -0.5 & 1.64 & 0.018 & 0.019 \\
\hline IS1347 & $4.48^{\star}$ & 2.17 & 0.07 & 1.64 & -0.037 & 0.019 \\
\hline $290 R$ & $12.81^{\star *}$ & 2.17 & $9.79^{\star \star}$ & 1.64 & $0.036^{*}$ & 0.019 \\
\hline
\end{tabular}

${ }^{*},{ }^{* *}=$ Significant at the 0.05 and 0.01 probability level, respectively

effects in most of the crosses were not significant for growth after heat exposure, which explained the lack of high heterosis in the $F_{1}$ generation. These results indicate that selecting potential heat tolerant lines for hybrid production should improve female parents with poor HTI. Additive genetic effects were predominant in coleoptile elongation recovery under heat stress in most of the crosses. Epistasis was important only in a few crosses. Individual genetic effects in some crosses were positive and negative which indicates the diversity in the genotypes used. 
TABLE 6. Best fit of genetic models and estimatesof genetic effects from generations means analysis for coleoptile elongation $(\mathrm{mm})$ without (UNG) exposure to heat stress for 12 sorghum test crosses (2 testers $\times 4$ lines)

\begin{tabular}{|c|c|c|c|c|c|c|}
\hline \multirow[t]{2}{*}{ Crosses } & \multicolumn{5}{|c|}{ Genetic effects \pm SE } & \multirow[b]{2}{*}{$\mathrm{dd}$} \\
\hline & $\mathrm{m}$ & a & $d$ & aa & $\mathrm{ad}$ & \\
\hline Ck60A x IS20969 & $67.5 \pm 3.0^{* *}$ & $4.93 \pm 1.6$ & $27.2 \pm 5.8$ ** & - & - & - \\
\hline N250A x IS20969 & $75.6 \pm 2.5 * \star$ & $2.07 \pm 1.4$ & $17.3 \pm 4.9 * *$ & - & - & - \\
\hline N252A x IS20969 & $73.4 \pm 1.4$ ** & $5.00 \pm 1.6 * *$ & $10.7 \pm 4.8$ & - & - & - \\
\hline Ck60A x Segaolane & $60.0 \pm 3.1^{\star \star}$ & $1.67 \pm 2.1$ & $14.4 \pm 7.3$ & & & \\
\hline N250A x Segaolane & $73.1 \pm 2.5^{\star \star}$ & $42.7 \pm 6.4^{\star \star}$ & $40.2 \pm 7.2$ ** & $21.5 \pm 5.0$ ** & $41.6 \pm 6.1$ ** & $68.6 \pm 15.4^{\star \star}$ \\
\hline N252A $x$ Segaolane & $71.6 \pm 0.9 * *$ & $2.28 \pm 1.3^{\star \star}$ & $5.3 \pm 3.5$ & - & - & - \\
\hline Ck604 x IS1347 & $57.7 \pm 3.0^{* *}$ & $1.88 \pm 2.0$ & $9.6 \pm 7.0$ & - & - & - \\
\hline N250 x IS1347 & $67.7 \pm 2.4^{\star \star}$ & $1.62 \pm 1.1$ & $3.4 \pm 4.1$ & - & - & - \\
\hline N252 x IS1347 & $66.3 \pm 2.0 * *$ & $1.74 \pm 1.0$ & $4.2 \pm 3.6^{*}$ & - & - & - \\
\hline CK604 x 290R & $59.9 \pm 2.5^{\star \star}$ & $13.68 \pm 1.5^{\star \star}$ & $8.9 \pm 4.5^{*}$ & - & - & - \\
\hline $\mathrm{N} 250 \mathrm{~A} \times 290 \mathrm{R}$ & $60.01 \pm 1.0^{\star \star}$ & $16.02 \pm 1.2^{\star \star}$ & $6.3 \pm 4.4$ & - & - & - \\
\hline $\mathrm{N} 252 \mathrm{~A} \times 290 \mathrm{R}$ & $58.7 \pm 1.4^{\star \star}$ & $13.62 \pm 1.3^{\star \star}$ & $6.9 \pm 3.4^{*}$ & - & - & - \\
\hline
\end{tabular}

*, ** = significant at the 0.05 and 0.01 probablity levels respectively

$\mathrm{m}=$ mean based on $\mathrm{F} 2$ population, $\mathrm{a}=$ additive, $\mathrm{d}=$ dominance, $\mathrm{aa}=$ additive $\mathrm{x}$ additive, ad $=$ additive $\mathrm{x}$ dominance $\mathrm{dd}=$ dominance $\mathrm{x}$ dominance

_ = Lack of fit (effects not significant)

TABLE 7. Best fit genetic models and estimates of genetic effects from generation means analysis for coleoptile elongation (mm) following exposure heat stress (EXP) for twelve sorghum test crosses ( 3 testers $x 4$ lines)

\begin{tabular}{|c|c|c|c|c|c|}
\hline \multirow[b]{2}{*}{ Crosses } & \multicolumn{4}{|c|}{ Genetic effects \pm SE } & \multirow[b]{2}{*}{$\mathrm{ad}$} \\
\hline & $\mathrm{m}$ & a & $d$ & aa & \\
\hline Ck60A x IS20969 & $48.8 \pm 3.6$ ** & $14.6 \pm 6.1^{*}$ & $11.1 \pm 5.1$ & - & - \\
\hline N250A x IS20969 & $50.8 \pm 1.8^{\star \star}$ & $5.9 \pm 1.8^{\star \star}$ & $3.0 \pm 3.0$ & - & - \\
\hline N252A x IS20969 & $47.0 \pm 1.7^{\star \star}$ & $7.7 \pm 1.3^{\star \star}$ & $0.7 \pm 3.6$ & - & - \\
\hline Ck60A x Segaolane & $41.2 \pm 1.7^{\star \star}$ & $4.1 \pm 1.7^{* *}$ & $14.2 \pm 5.3$ & & \\
\hline N250A x Segaolane & $41.4 \pm 1.9^{\star \star}$ & $27.5 \pm 4.6$ ** & $30.7 \pm 5.6^{\star *}$ & $16.8 \pm 3.8^{\star \star}$ & $24.8 \pm 4.7^{\star \star}$ \\
\hline N252A $\times$ Segaolane & $42.6 \pm 1.4^{\star \star}$ & $0.2 \pm 0.82$ & $4.47 \pm 2.5^{\star}$ & & \\
\hline Ck604 x IS1347 & $41.1 \pm 2.5^{\star \star}$ & $2.8 \pm 1.43$ & $7.0 \pm 5.0$ & $6.49 \pm 3.09^{* *}$ & - \\
\hline N250 x IS1347 & $49.4 \pm 2.0^{\star \star}$ & $3.3 \pm 0.84^{\star *}$ & $6.3 \pm 2.9$ & & \\
\hline $\mathrm{N} 252 \times \mathrm{IS} 1347$ & $42.7 \pm 0.9 * *$ & $5.4 \pm 0.72^{\star *}$ & $6.5 \pm 2.5^{\star \star}$ & - & - \\
\hline CK604 x 290R & $33.8 \pm 1.9^{\star \star}$ & $12.9 \pm 1.41^{\star *}$ & $12.3 \pm 4.6$ & - & - \\
\hline $\mathrm{N} 250 \mathrm{~A} \times 290 \mathrm{R}$ & $33.4 \pm 0.7^{\star \star}$ & $11.1 \pm 0.93$ & $4.5 \pm 3.0$ & - & - \\
\hline $\mathrm{N} 252 \mathrm{~A} \times 290 \mathrm{R}$ & $33.5 \pm 0.9^{\star \star}$ & $9.3 \pm 0.79$ & $52 . \pm 2.7^{\star \star}$ & - & - \\
\hline
\end{tabular}

${ }^{*},{ }^{* *}=$ significant at the 0.05 and 0.01 probablity levels respectively; $m=$ mean based on F2 population, $a=$ additive, $d=$ dominance, $\mathrm{aa}=$ additive $\mathrm{x}$ additive, $\mathrm{ad}=$ additive $\mathrm{x}$ dominance; $\mathrm{dd}=$ dominance $\mathrm{x}$ dominance; - = Lack of fit (effects not significant) 
TABLE 8. Best fit of genetic models and estimates of genetic effects from generation means analyses for derived heat index (HTI) based on resumed coleoptile elongation for twelve sorghum test crosses ( 3 testers $\times 4$ lines)

\begin{tabular}{|c|c|c|c|}
\hline \multirow[t]{2}{*}{ Crosses } & \multicolumn{3}{|c|}{ Genetic effects \pm SE } \\
\hline & $\mathrm{m}$ & a & $d$ \\
\hline Ck60A x IS20969 & $0.60 \pm 0.02^{\star \star}$ & $0.02 \pm 0.01$ & $-0.15 \pm 0.04^{\star *}$ \\
\hline N250A x IS20969 & $.0 .65 \pm 0.04^{\star *}$ & $0.06 \pm 0.01^{\star \star}$ & $-0.02 \pm 0.05$ \\
\hline N252A x IS20969 & $0.64 \pm 0.02^{\star \star}$ & $0.06 \pm 0.01 * \star$ & $-0.04 \pm 0.05$ \\
\hline Ck60A x Segaolane & $0.59 \pm 0.01^{\star \star}$ & $-0.05 \pm 0.01^{\star \star}$ & $0.07 \pm 0.06$ \\
\hline N250A $\times$ Segaolane & $0.58 \pm 0.04$ & $-0.20 \pm 0.01$ & $0.05 \pm 0.51$ \\
\hline N252A x Segaolane & $0.61 \pm 0.03$ & $-0.02 \pm 0.01$ & $-0.01 \pm 0.01$ \\
\hline Ck604 x IS1347 & $0.67 \pm 0.04$ & $0.03 \pm 0.02$ & $0.02 \pm 0.06$ \\
\hline $\mathrm{N} 250 \times \mathrm{IS} 1347$ & $0.66 \pm 0.03^{\star \star}$ & $0.06 \pm 0.01^{\star \star}$ & $0.05 \pm 0.04$ \\
\hline N252 x IS1347 & $0.65 \pm 0.04^{\star \star}$ & $0.06 \pm 0.01^{\star \star}$ & $-0.75 \pm 0.04$ \\
\hline CK604 x 290R & $0.58 \pm 0.01 * *$ & $-0.07 \pm 0.02^{\star \star}$ & $0.04 \pm 0.06$ \\
\hline $\mathrm{N} 250 \mathrm{~A} \times 290 \mathrm{R}$ & $0.55 \pm 0.01$ ** & $-0.04 \pm 0.01^{\star \star}$ & $0.02 \pm 0.05$ \\
\hline $\mathrm{N} 252 \mathrm{~A} \times 290 \mathrm{R}$ & $0.57 \pm 0.01^{\star *}$ & $-0.04 \pm 0.01^{\star *}$ & $-0.04 \pm 0.03$ \\
\hline
\end{tabular}

${ }^{*},{ }^{* *}=$ significant at the 0.05 and 0.01 probablity levels respectively; $\mathrm{m}=$ mean based on $\mathrm{F} 2$ population, $\mathrm{a}=$ additive, $\mathrm{d}=$ dominance, aa = additive $\mathrm{x}$ additive, $\mathrm{ad}=$ additive $\mathrm{x}$ dominance; $\mathrm{dd}=$ dominance $\mathrm{x}$ dominance; $-=$ Lack of fit (effects not significant)

The method used to detect significant differences between parents, and the type of gene action involved in this study are useful to a plant breeder to reduce the number of entries before embarking on a field trial. For improvement of coleoptile elongation under heat stress the breeder should use selection procedures emphasizing GCA.

\section{REFERENCES}

Allan, R.E., Vogel, O.A. and Burkeigh, 1.R. 1962. Length an estimated number of coleoptile elongation parenchyma cells of 6 wheat sections grown at two temperatures. Crop Science 2:522-524.

Comstock, R. and Robinson, E. 1948. The components of genetic variance in populations biparental progenies and their use in estimating the average degree of dominance. Biometrics 4:254-266.

Hallauer, R.A. and Miranda, B. 1988. Quantitative Genetics in Maize Breeding Iowa State University Press, Ames.

Howarth, C.I. 1989. Heat shock proteins in Sorghum bicolor and Pennisetum amerieanum I. genotypical and deve- lopmental variation during seed germination. Plant cell and environment 12: 471-477.

Levitt, I. 1980. Responses of plants to environmental stress. Vol 1. Chilling, Freezing and High Temperature stress. Academic Press. New York.

Mather, K. and Jinks, J.L. 1982. Biometrical Genetics. $3^{\text {rd }}$ Edition. Chapman and Hill, London, UK.

Peacock, J.M., Soman, P., Jayachandran, R., Rani, A.U., Howarth C.J. and Thomas, A.1993. Effects of high soil surface temperature on seedling survival in pearl millet. Experimental Agriculture 29:215-225.

Miller, F.R. 1982. Genetic and improvemental response characteristics of sorghum. In: Sorghum in the Eighties. Proceedings of the International Symposium on Sorghum. House, L.R., Mughogho, L.K and Peacock, J.M. (Eds.), pp. 393-402.

Peacock, J.M. 1982. Response and tolerance of sorghum to temperature stress. In: Sorghum in the eighties. Proceedings of the International Symposium on Sorghum, Patancheru. LR House et al. (Ed.), pp. 143160. India. 2-7 Nov. 1981. ICRISAT. Patancheru. India. 
Radford, B.1., Wood, I.M., Beavis, C.H., Walsh, P.A., Vereritz, A.M., Hazard, W.J.L., Wade, L.I., Hughes, J., Robertson L.N., Page I.R., Wollison, A.S. and Spackman, G.B. 1989. A survey of the establishment of commercial sorghum and sunflower crops in the Central Highlands of Queensland and analysis of the effects of level and evenness of establishment on grain sorghum. Occasional Publication 43. Australian Institute of Agricultural Sciences Brisbane.

Ross, W.M. and Gardner, C.O. 1983. The mechanics of population improvement in sorghum. Proceedings of Plant Breeding
Methods and Approaches in Sorghum workshop for Latin America. CIMMYT.

Setimela, P.S., Andrews, D.J., Partridge, J. and Eskridge, K.M. 2004. Screening sorghum seedlings for heat tolerance using a laboratory method. European Journal Agronomy 23:103-107.

Thomas, G.L. and Miller, F.R. 1979. Base temperature for germination of temperate and tropically adapted sorghum. In Proc. Biennial Grain Sorghum Res. and Utilization Com., 11th Feb. 28- Mar. 2. 1079. Grain Sorghum Producers Association, Lubbock, TX. p. 24. 